\title{
Dhikr And Wudu As Therapy On Spiritual Distress In Hypertension Patients
}

\author{
Erlin Indah Kusumadiyanti ${ }^{1}$, Rendi Editya Darmawan ${ }^{1}$, Siti Lestari ${ }^{1}$ \\ ${ }^{1}$ Department of Nursing Poltekkes Kemenkes Surakarta, Indonesia \\ Corresponding author: Rendi Editya Darmawan; Jalan Letjen Sutoyo, Mojosongo, Surakarta; \\ +6285354557665; ndik_ners@yahoo.com
}

\begin{abstract}
Background: Hypertension is an increase in blood pressure that can pump blood throughout the body within limits above normal. Hypertension is the number one cause of death in the world and is more common in the elderly. This causes various disturbances to a person, one of which is spiritual distress. One of the efforts that can be done to reduce the level of spiritual distress is dhikr and wudu therapy.

Purpose: The effect of Dhikr and Wudu as therapy on spiritual distress in hypertantion patients.

Methods: this study used a Quasy Eexperiment Nonequivalent Control Group Design study on 36 respondents who had hypertension, which consisted of 18 for the intervension group and 18 for the control group.

Results: the results of the Wilcoxon test in the intervention group showed that the $p$ value of changes in the level of spiritual distress before and after being given dhikr and wudu therapy was 0,000 , indicating $p>0,05$. While the results of the Paired Sample $T$ Test in the control group obtained $p$ value of 0.010 indicating $p>0,05$. The results of the mann whitney test showed that the $\mathrm{p}$ value was 0,000 indicating $p<0,05$

Conclusion: there is an effect of dhikr and wudhu therapy on spiritual distress in patients with hypertension.
\end{abstract}

\section{Keywords:}

Hypertension; spiritual distress; dhikr therapy; wudu.

\section{BACKGROUND}

Non-communicable diseases which are included in cardiovascular diseases that are most common to people and the number one killer cause of death in the world is hypertension (Kemenkes RI, 2019). The prevalence of hypertension in the world is $22 \%$ of the total world population (Kemenkes RI, 2019). In Indonesia, the prevalence of hypertension reaches $34.1 \%$ with a mortality rate of 427,218 people (Health Research and Development Agency for Health Research and Development Center for Humanities and Health Management, 2018). In East Java, it is ranked the sixth highest prevalence of hypertension in Indonesia, which is 36.32\% (Health Research and Development Agency for Health Research and Development Center for Humanities and Health Management, 2018). Meanwhile in 2017, hypertension was in the third position with the highest number of cases in Pacitan district with 11,312 cases (Dinkes, 2017 
Hypertension by increasing distolic blood pressure $\geq 140 \mathrm{mmHg}$ and diastolic pressure $\geq 90 \mathrm{mmHg}$ (Indonesian Ministry of Health, 2019). Increased with increased blood pressure and undiagnosed or untreated blood pressure conditions, hypertension can cause complications that can attack organs in the body and diseases such as stroke, kidney failure and heart failure (Kemenkes RI, 2019). In addition, people with hypertension will also experience changes in lifestyle such as monitoring to be diligent in controlling, taking medication, keeping them from being stressed, and eating patterns and activities that must be regulated. If a person does not have good coping, it will cause various disturbances, one of which is spiritual distress. According to Shirley OtisGreen et al. In Wahyuni (2016), someone who experiences pain, anger, fear, pain, loss of self-control, conflicting thoughts, and low self-esteem experiences spiritual distress.

Spiritual distress is a condition in which individuals experience disturbances due to spiritual inadequacy which is a source of enthusiasm and life expectancy, so that someone will blame himself, others, and even blame God for what happened (Monod et al., 2010). According to Huffman and Christopher M Celano (2010) spiritual distress can cause anxiety, when a person experiences changes in the hormone cortisol will increase which can increase the vasoconstrictor response of blood vessels. Vasocontriction causes a decrease in blood flow to the kidneys resulting in the release of renin which stimulates angiotensin I. Then it is converted into angiotensin II, the vasoconstriction becomes stronger so that it stimulates aldosterone secretion which causes an increase in intravascular volume, so that blood pressure becomes high (Manurung, 2016).

The SIKI book (2018) states that spiritual distress can be overcome by providing spiritual support, one of which is by facilitating worship activities (PPNI, 2018). According to the Indonesian Ministry of Health (2019), it is explained that the management of hypertension can also be done non-pharmacologically, namely by providing relaxation. Dzikir and wudu therapy, apart from being a means of getting closer to the creator, also has benefits in terms of one's physical and psychological health. This is in accordance with the research conducted by Kumala et al. (2017) and Nur Anggraieni (2014) who state that dzikir and wudu therapy can provide a calm or relaxing effect. Research conducted by Dwi Ningsih et al. (2018) also explained that spiritual relaxation can reduce sympathetic nervous activity through spiritual belief in order to control their physical state. According to Bahadorfar (2014) the state of relaxation will stimulate the secretion of the endhorphrin hormone and the hormone cortisol to decrease. However, many health workers, especially nurses, only focus on the physical aspects, while the psychological aspects, especially the spiritual aspects, are still largely forgotten (Nuraeni et al., 2015). Based on this phenomenon, researchers are interested in conducting research on the effect of dhikr and wudu therapy on spiritual distress in hypertensive sufferers.

For complete information author guidelines please

http://ejournal.poltekkes-smg.ac.id/ojs/index.php/jnj/about/submissions\#authorGuidelines 


\section{OBJECTIVE}

Aim of study is to analize the effect of dhikir and wudu therapy on spiritual distress in hypertensive sufferers.

\section{METHODS}

This study used a Quasy Eexperiment Nonequivalent Control Group Design research design. The sampling technique used in this study was purposive sampling, the sample taken from hypertension patients at the Sumber Waras Elderly Posyandu in Plumbungan Village. The number of samples used in this study were 36 respondents from a total population of 40 people. The total sample was divided into two groups, namely 18 respondents in the intervention group and 18 respondents in the control group. The instrument used in this study was the Spiritual Distress Spiritual Assessment Tool (SDAT) to measure spiritual distress in respondents with hypertension by means of structured interviews, analyzing interview results, and determining scores, as well as Standard Operating Procedures (SOP) for dzikir and wudu therapy.

Researchers conducted research based on established research ethics and were declared ethical with an ethics license number, namely 66 / II / HREC / 2021. This research was conducted at the Elderly Posyandu at Sumber Waras, Plumbungan Village, Kebonagung District, Pacitan Regency, East Java on February 20 - 1 March 2021. In this study, researchers involved 1 assistant researcher who will assist researchers in adding understanding of dzikir and wudu. Researchers approached respondents by paying attention to health protocols during the pandemic, namely wearing masks, maintaining distance, and always showing their hands. Then the researcher provides an explanation and the purpose of the study and answers the respondent that participation in the research is to and is kept confidential. Then the researcher identified according to the inclusion and exclusion criteria to suit the objectives and conducted interviews using the SDAT instrument to find out any spiritual distress in the respondent and as a pretest. After the sample was determined, respondents who experienced spiritual distress and who agreed to become research respondents contacted the informed consent sheet. Respond to fill in demographic data and do common goal setting. Respondents in the intervention group were given an understanding of dzikir and wudu therapy and their impact on spiritual suffering in hypertensive sufferers who were assisted by enumerators, and were also given guidance on the implementation of dzikir and wudu according to the SOP.

During the dzikir therapy action 4 times in 7 days with a duration of 20-30 minutes each and every time it is done and done in a special way, as well as wudu for every prayer, respondents are monitored through the WhatsApp group or cell phone and activity sheets to ensure the respondent takes action. The researcher made a visit with the enumerators on the $3 \mathrm{rd}$ and 5 th day to provide further understanding. After 7 days, the

For complete information author guidelines please

http://ejournal.poltekkes-smg.ac.id/ojs/index.php/inj/about/submissions\#authorGuidelines 
spiritual respondent's distress level was measured again as a posttest. Respondents in the control group were not given dhikr and wudu therapy treatment, but in accordance with the SOP or advice given by local health personnel, and were asked to perform dzikir and wudu therapy by the researcher at the end of the study.

The data analysis used in this study was univariate analysis to see the level of spiritual distress before the test in the intervention group and the control group. Meanwhile, bivariate analysis includes data normality test using the Saphiro Wilk test. Paired sample test for intervention interventions using the Wilcoxon test. Paired sample test of the control group used the Paired Sample T Test. The unpaired sample test used the Mann Whitney test. Hypothesis testing uses a confidence level of $95 \%$ or $\alpha<0.05$.

\section{RESULTS}

Table 1 shows that the total group of intervention respondents was 18 respondents, most of the respondents were female by $14(77.8 \%)$ and male by $4(22.2 \%)$. The total control group was 18 respondents, most of the respondents were female by $13(72.2 \%)$ and male by $5(27.8 \%)$.

Table 2. Respondents showed that in the intervention group aged 60-69 years were 7 (38.9\%), 70-79 years were 7 (38.9\%), and 80-89 years were 4 (22.2\%). Respondents in the control group aged 60-69 years were $6(33.3, \%), 70-79$ years were $9(50 \%)$, and 80 89 years were $3(16.7 \%)$.

Table 3 shows that the spiritual distress score of the intervention group was a score between before and after which showed a positive value (there was a decrease in spiritual pressure) by $100 \%$. Meanwhile, in the control group there was a change in the score of spiritual distress between before and after which showed a negative value (increase in spiritual distress) by $33 \%$ and there was no change (constant spiritual distress) by $67 \%$.

Table 4 shows that the results of the Saphiro Wilk test obtained $p$ value $=0.076$ for the intervention group pretest, $p=0.007$ for the intervention group posttest, $p=0.072$ for the control group pretest, and $p=0.139$ for the control group posttest. Thus the results of $p$ count $<0.05$, which means that the data is not normally distributed and the results of $\mathrm{p}$ count $>0.05$ are normally distributed.

Table 5 shows the results of the homogeneity test obtained by $\mathrm{p}$ count $=0.656$, where $\mathrm{p}$ count $>0.05$, which means that the data for the intervention group and the group have homogeneous data variants.

Table 6.shows the results of the Wilcoxon test on the spiritual distress of the intervention group using an interval data scale where $p$ count $=0,000$, so that $p$ count $<0.05$ then Ho is rejected and $\mathrm{Ha}$ is accepted, meaning that there is a difference between the level of spiritual distress for the pretest and posttest, so it can be It is presented that there is an effect of dzikir and wudu therapy on spiritual distress in hypertensive sufferers. The results of the Paired Sample T Test in the control group used an interval 
data scale of $p=0.010$, so that $p$ count $>0.05$, which means there is no difference between the level of spiritual distress for the pretest and posttest because the researcher did not give intervention.

Table 7 shows the results of the Mann Whitney test on the distress variable of the spiritual intervention group and the Asymp value control group. Sig (2-tailed) of 0.000, so it can be denied that $\mathrm{p}$ count $<0.05$, it can be ignored that there is a significant influence between the intervention group that was given dhikr and wudu therapy and the control group that was not given dzikir and wudu therapy. Thus it can be said that there is an effect of dhikr and wudu therapy on spiritual pressure in people with hypertension.

Table 1. Frequency Distribution of Gender of Respondents in the Intervention and Control Groups

\begin{tabular}{llcccc}
\hline \multirow{2}{*}{ No } & \multirow{2}{*}{ Gender } & \multicolumn{2}{c}{ Intervention Group } & \multicolumn{2}{c}{ Control Group } \\
\cline { 3 - 6 } & & Frequency & Percen & Frequency & Percen \\
\hline 1 & Male & 4 & 22,2 & 5 & 27,8 \\
2 & Female & 14 & 77,8 & 13 & 72,2 \\
\hline & Total & 18 & 100 & 18 & 100 \\
\hline
\end{tabular}

Table 2. Frequency Distribution of Age of Respondents in the Intervention and Control Groups

\begin{tabular}{cccccc}
\hline \multirow{2}{*}{ No } & \multirow{2}{*}{ Age } & \multicolumn{2}{c}{ Intervention Group } & \multicolumn{2}{c}{ Control Group } \\
\cline { 3 - 6 } & & Frequency & Percen & Frequency & Percen \\
\hline 1 & $60-69$ & 7 & 38,9 & 6 & 33,3 \\
2 & $70-79$ & 7 & 38,9 & 9 & 50,0 \\
3 & $80-89$ & 4 & 22,2 & 3 & 16,7 \\
& & & & & 100 \\
\hline & Total & 18 & 100 & 18 & \\
& & & & & \\
\end{tabular}


Table 3. Frequency Distribution of Pre-test and Post-test Spiritual Distress Scores

\begin{tabular}{|c|c|c|c|c|c|c|}
\hline \multirow{2}{*}{ No } & \multicolumn{3}{|c|}{ Intervention Group } & \multicolumn{3}{|c|}{ Control Group } \\
\hline & Pre & Post & Difference & Pre & Post & Difference \\
\hline 1 & 7 & 2 & 5 & 5 & 5 & 0 \\
\hline 2 & 7 & 3 & 4 & 3 & 3 & 0 \\
\hline 3 & 7 & 4 & 3 & 5 & 6 & -1 \\
\hline 4 & 6 & 2 & 4 & 5 & 5 & 0 \\
\hline 5 & 8 & 6 & 2 & 6 & 7 & -1 \\
\hline 6 & 6 & 4 & 2 & 8 & 8 & 0 \\
\hline 7 & 6 & 1 & 5 & 6 & 7 & -1 \\
\hline 8 & 5 & 1 & 4 & 6 & 6 & 0 \\
\hline 9 & 4 & 1 & 3 & 6 & 7 & -1 \\
\hline 10 & 4 & 2 & 2 & 8 & 8 & 0 \\
\hline 11 & 8 & 4 & 4 & 3 & 4 & -1 \\
\hline 12 & 4 & 2 & 2 & 7 & 7 & 0 \\
\hline 13 & 3 & 1 & 2 & 5 & 5 & 0 \\
\hline 14 & 5 & 2 & 3 & 6 & 6 & 0 \\
\hline 15 & 8 & 4 & 4 & 6 & 6 & 0 \\
\hline 16 & 3 & 1 & 2 & 4 & 5 & -1 \\
\hline 17 & 4 & 2 & 2 & 3 & 3 & 0 \\
\hline 18 & 4 & 2 & 2 & 3 & 3 & 0 \\
\hline \multirow{3}{*}{\multicolumn{2}{|c|}{ Total }} & Increase & $0 \%$ & Total & Increase & $33 \%$ \\
\hline & & Decreased & $100 \%$ & & Decreased & $0 \%$ \\
\hline & & Constantly & $0 \%$ & & Tetap & $67 \%$ \\
\hline
\end{tabular}

Table 4.Saphiro Wilk Test Results

\begin{tabular}{cccccc}
\hline No & $\begin{array}{c}\text { Spiritual } \\
\text { Distress }\end{array}$ & $\begin{array}{c}\text { Intervention } \\
\text { Group P } \\
\text { Value }\end{array}$ & Information & $\begin{array}{c}\text { Control } \\
\text { Group P } \\
\text { Value }\end{array}$ & Information \\
\hline 1 & Pre & 0,076 & Normal & 0,072 & Normal \\
2 & Post & 0,007 & Abnormal & 0,139 & Normal \\
\hline
\end{tabular}

Table 5. Homogeneity Test Results

\begin{tabular}{lllll}
\hline \multirow{2}{*}{ No } & \multicolumn{1}{c}{ Variable } & \multicolumn{2}{c}{ Criteria } & \multirow{2}{*}{ Information } \\
\cline { 3 - 3 } & & $\mathrm{P}>0,05$ & $\mathrm{P}$ value & \\
\hline 1 & Pretest Intervention Group & & & \\
2 & Posttest Intervention Group & & & \\
3 & Pretest Control Group & $\mathrm{P}>0,05$ & 0,656 & Homogen \\
4 & Posttest Control Group & & & \\
\hline
\end{tabular}


Table 6. Wilcoxon Test and Paired Sampel T Test Results

\begin{tabular}{|c|c|c|c|c|c|c|}
\hline \multirow{2}{*}{ No } & \multicolumn{2}{|c|}{$\begin{array}{l}\text { Intervention } \\
\text { Group }\end{array}$} & \multirow{2}{*}{ Information } & \multicolumn{2}{|c|}{ Control Group } & \multirow{2}{*}{ Information } \\
\hline & $\begin{array}{c}P<0,0 \\
5\end{array}$ & $\begin{array}{c}P \\
\text { Value }\end{array}$ & & $P<0,05$ & $P$ Value & \\
\hline 1 & $\begin{array}{c}P<0,0 \\
5\end{array}$ & 0,000 & $\begin{array}{l}\text { There is } \\
\text { effect }\end{array}$ & $P>0,05$ & 0,010 & $\begin{array}{c}\text { There is no } \\
\text { effect }\end{array}$ \\
\hline
\end{tabular}

Table 7. Mann Whitney Test Results

\begin{tabular}{llcc}
\hline No & \multicolumn{1}{c}{ Variable } & Frequency & Asymp. Sig (2-tailed) \\
\hline 1 & $\begin{array}{l}\text { The Spiritual Distress of } \\
\text { Intervention Group }\end{array}$ & 18 & 0,000 \\
2 & $\begin{array}{l}\text { The Spiritual Distress of } \\
\text { Control Group }\end{array}$ & 18 & \\
\hline
\end{tabular}

\section{DISCUSSION}

\section{A. The Level of Spiritual Distress Before and After Dzikir and Wudu Therapy}

The results of the spiritual distress pretest in the intervention group before doing dzikir and wudu therapy were 7 respondents in the light category and 11 in the moderate category with a minimum value of 3 and a maximum value of 8 . The posttest results in the mild category were 17 respondents and the moderate category was 1 respondent with a minimum value of 1 and a maximum value 6 . While the results of the spiritual distress pretest in the control group after 7 days without being given dzikir and wudu therapy were 5 respondents in the light category, and in the moderate category 13 with a minimum value of 3 and a maximum 3 and a maximum of 8 . This is in accordance with research conducted by Miranda et al (2019) and Farida (2018) which shows that there is a change or decrease in spiritual pressure before and after being given treatment.

The results showed that the data from the Wilcoxon test (using an interval data scale) showed that the therapeutic actions of dzikir and wudu in the intervention group affected the level of spiritual distress. This is evidenced by a significant change in spiritual pressure before and after the action with a probability value $<0.05$ and $p$ count $=0.000$. Thus it can be accepted that Ho is rejected and Ha, which means that there is an effect of dhikr and wudu therapy on spiritual pressure in people with hypertension. While the results of the Paired Sample T Test (using an interval data scale) in the control group that were not given dhikr and wudu therapy, it was found that there was no change in spiritual pressure before and after the probability value $>0.05$ and $p$ count $=0.010$. So that doing dzikir and wudu therapy will have a good effect, not only providing a means of getting closer to the Creator but also providing benefits both in 
terms of physical and psychological health in the form of relaxation which can reduce the level of spiritual distress.

This study is in line with research conducted by Kumala et al. (2017), Utomo (2015), and Nur Anggraieni (2014) who state that dzikir and wudu therapy is effective in providing calm and relaxation. Based on the theory put forward by Bahadorfar (2014) states that a relaxed state due to the effect of massage water spray during wudu will stimulate the secretion of endorphin hormones and at the same time will reduce the hormone cortisol.

In patients with hypertension with blood pressure and blood pressure conditions that are not diagnosed or treated properly, complications can affect the eyes, brain, heart, kidneys and peripheral blood vessels, as well as diseases such as stroke, kidney failure and heart failure (Kemenkes RI, 2019). In addition, people with hypertension will also experience changes in lifestyle, which will monitor them to be diligent in controlling, taking medication, avoiding stress, and eating patterns and activities that must be regulated. In problems like this, various disturbances will arise in a person such as the suffering of a person who does not have good coping in dealing with problems. According to Nasution (2007), distress is stress that comes from negative pressure in a person. Shirley Otis - Green et al. In Wahyuni (2016) also explains that someone who experiences pain, anger, fear, pain, loss of control, conflicting thoughts, and low self who does not experience spiritual distress.

Dhikr therapy attempts to get closer to Allha SWT by remembering and saying Allah SWT's lafadz-lafadz (Kumala et al., 2017). While wudu according to Sayyid Sabit in Lela \& Lukmawati (2016) is an activity of purifying using water, and is a means of cleansing the soul starting from the outermost (physical) to the innermost (spiritual) side. The effect of dhikr and wudu therapy that is carried out in earnest on spiritual distress in hypertensive sufferers can provide physical relaxation and mental peace. Spiritual relaxation is a person's attempt to achieve a disturbing state by decreasing sympathetic nervous activity through the client's spiritual religious beliefs in order to control his physicality (Dwi Ningsih et al., 2018). This is in accordance with the research conducted by Dwi Ningsih et al. (2018) which states that the fulfillment of a client's spiritual needs reduces suffering and helps heal physical and mental illnesses.

When conditions are calm, the body will relax, this is in accordance with the word of Allah SWT in surah Ar-Rad verse 28 which means:

"That is those who believe and their hearts will be at peace by remembering Allah. Remember that just by remembering Allah the heart is calm ". 


\section{B. Differences in the Effect of the Intervention Group with the Giving of Dhikr and Wudu Therapy with the Control Group on Spiritual Distress in Patients with Hypertension}

The results of this study showed that the results of the Mann Whitney test on the posttest showed a difference in the results of the level of spiritual distress between the two intervention and control groups. This is evidenced by the probability value $<0.05$ and $\mathrm{p}$ count $=0.000$. Thus it can be accepted that Ho is rejected and Ha, which means that there is a significant effect between the intervention group that is given dzikir and wudu therapy and the control group that is not given dhikr and wudu therapy on spiritual pressure in hypertensive sufferers. This is in accordance with research conducted by Albani (2014) which states that dzikir and wudu therapy has an effect or can reduce the level of distress in internal medicine patients quite well.

According to S. M. Monod et al. (2010) spiritual distress is a condition in which individuals experience disturbances where their spiritual needs are not fulfilled which is a source of spirit and life expectancy, so that someone experiencing spiritual distress will blame himself, others, or even blame God for what happened. When an individual feels unable to deal with the pressures in his life, what happens is stress, anxiety, and even spiritual pressure. According to Jeff C Huffman \& Christopher M Celano (2010) spiritual distress can cause anxiety. Prolonged anxiety causes blood pressure to rise and causes various complaints.

A person who experiences spiritual distress due to anxiety due to his illness needs help to overcome it so that his condition does not get worse. One of the therapies that can be given in addition to pharmacological therapy in the form of antihypertensive drugs or the other is spiritual healing and the ones used in this research are dhikr and wudu therapy. Spiritual is a spectrum of positive behaviors and emotions such as experiences, values, and goals in life when a person relates to transcendence and is manifested in relationships with other people, oneself, and something higher than himself (Monod et al., 2010). In research conducted by Anggraieni (2014) states that the existence of religious factors, namely dzikir and wudu can increase life expectancy, reduce, reduce depression, lower blood pressure, and improve the quality of life for patients with cancer and heart disease.

The results of this analysis prove that interventions with dhikr and wudu therapy are proven to be effective and very significant in reducing the level of spiritual pressure in people with hypertension.

\section{CONCLUSION}

There is an effect of dzikir and wudu therapy on spiritual distress in people with hypertension. 


\section{REFERENCES}

Albani, Y. (2014). Bimbingan Spiritual Dalam Mengurangi Tingkat Distress Pasien Di Ruang Penyakit Dalam. Universitas Islam Negeri Sunan Gunung Djati Bandung.

Bahadorfar, M. (2014). A Study of Hydrotherapy and Its Health Benefits. International Journal of Research, 1(8), 294-305. http://edupediapublications.org/journals/index.php/ijr/article/view/507

Dinkes. (2017). Jumlah Kasus 10 Penyakit Terbanyak di Kabupaten Pacitan.

Dwi Ningsih, E., Mukarromah, I., \& Yani, L. (2018). Pengaruh Terapi Relaksasi Spiritual Terhadap Tingkat Stres Pasien Gagal Ginjal Kronis yang Menjalani Hemodialisis. Journal of Nursing Care \& Biomolecular, 3(2), 71.

Farida, U. (2018). Penerapan Spiritual Care Pada Pasien Distress Spiritual Di RSJD Dr. Amino Gondohutomo Semarang [Universitas Islam Sultan Agung Semarang]. http://repository.unissula.ac.id/id/eprint/13784

Jeff C Huffman , Christopher M Celano, J. L. J. (2010). The relationship between depression, anxiety, and cardiovascular outcomes in patients with acute coronary syndromes. PubMed. https://doi.org/10.2147/ndt.s6880

Kemenkes RI. (2019). Hipertensi Si Pembunuh Senyap. Kementrian Kesehatan RI, 1-5. https://pusdatin.kemkes.go.id/resources/download/pusdatin/infodatin/infodatin-hipertensisi-pembunuh-senyap.pdf

Kumala, O. D., Kusprayogi, Y., \& Nashori, F. (2017). Efektivitas Pelatihan Dzikir dalam Meningkatkan Ketenangan Jiwa pada Lansia Penderita Hipertensi. Psympathic: Jurnal Ilmiah Psikologi, 4(1), 55-66. https://doi.org/10.15575/psy.v4i1.1260

Lukmawati, L. dan. (2016). "KETENANGAN": MAKNA DAWAMUL WUDHU (Studi Fenomenologi Pada Mahasiswa UIN Raden Fatah Palembang). Psikis: Jurnal Psikologi Islami, 1(2), 55-66.

Manurung, N. (2016). Keperawatan Medikal Bedah Konsep Mind Maping dan NANDA NIC NOC (Jilid 2). Jakarta: Tans Info Media.

Miranda, T. P. S., Caldeira, S., Oliveira, H. F. de, Iunes, D. H., Nogueira, D. A., Chaves, E. de C. L., \& Carvalho, E. C. de. (2019). Intercessory Prayer on Spiritual Distress, Spiritual Coping, Anxiety, Depression and Salivary Amylase in Breast Cancer Patients During Radiotherapy: Randomized Clinical Trial. Journal of Religion and Health, 59, pages3. https://link.springer.com/article/10.1007/s10943-019-00827-5

Monod, S. M., Rochat, E., Büla, C. J., Jobin, G., Martin, E., \& Spencer, B. (2010). The spiritual distress assessment tool: An instrument to assess spiritual distress in hospitalised elderly persons. BMC Geriatrics, 10. https://doi.org/10.1186/1471-2318-10-88

Nasution, I. K. (2007). Stres Pada Remaja. Universitas Sumatra Utara, 1-26.

Nur Anggraieni, W. (2014). Pengaruh terapi dzikir untuk menurunkan stress pada penderita hiprtensi esensial. Jurnal Intervensi Psikologi, 6(1), 81-102. www.purtierplacenta.com,

Nuraeni, A., Ibrahim, K., \& Agustina, H. (2015). Makna Spiritualitas pada Klien dengan Sindrom Koroner Akut. Jurnal Keperawatan Padjadjaran, 1. https://doi.org/10.24198/jkp.v1i2.55

PPNI. (2018). Standar Intervensi Keperawatan Indonesia: Definisi dan Tindakan keperawatan (Edisi 1). Jakarta: DPP PPNI.

Utomo, I. M. (2015). Pengaruh Wudhu Terhadap Kecemasan Saat Menghadapi Ujian Praktikum Pada Mahasiswi Keperawatan Uin Syarif Hidayatullah Jakarta. ii-113.

Wahyuni, H. F. (2016). Distress Spiritual Pada Pasien Sindrom Koroner Akut Yang Menjalani Perawatan Intensif Di RSUP DR. Hasan Sadikin Bandung. https://repository.unpad.ac.id/frontdoor/index/index/year/2020/docId/35243 